\section{Earth, Water, Ice and Fire: \\ Two Hundred Years of Geological Research in the English Lake District}

\author{
By David R. Oldroyd
}

Geological Society, London, Memoir

25, 2002; hardback, 344 pages, 175

illustrations, list price $£ 85$. ISBN 186239-107-6

The book is divided into 21 chapters with 23 pages of references and an index. It is laid out chronologically with a thematic overprint. Starting in the early nineteenth century, the book is about the geologists who worked in the Lake District as much as the research they did. Throughout it the author gives biographical details of both the main and the minor players. The Lake District is an inlier of Lower Palaeozoic rocks in the north-west of England made up of three main rock units: in ascending order they are the Skiddaw Group of grey slates and turbidites, the Borrowdale Volcanic Group and the Windermere Supergroup of basinal deposits. There are major intrusive bodies and Quaternary deposits. The research on all of them is covered. Only metallogenesis receives little attention.

The book divides up naturally into three parts. The first six chapters cover the period up to the Second World War. The next seven chapters cover the late 1940s to 1981. The last eight are about the modern period of research and his concluding thoughts.

In the first chapter, the author introduces men like Joseph Fryer, who, in 1814, made the first geological map of part of the Lake District, and Jonathan Otley, who by 1820 had recognised the tripartite division of the stratified rocks. These men laid the foundations for research by Adam Sedgwick (Chapter 2), Robert Harkness, Henry Alleyne Nicholson, Charles Lapworth (Chapter 3), the Geological Survey staff who mapped the area between 1866 and 1877 (Chapter 4), John Marr and Alfred Harker (Chapter 5), who dominated research in the Lake district up to the First World War. The disagreement between Sedgwick and Murchison over the position of the boundary between the Cambrian and the Silurian and its consequences run through this section of the book, as do the rise and fall of the catastrophist theory, Barrande's theory of colonies, the conflict between amateurs (university men) and professionals (Survey men), the difficulties caused by palaeontologically-led as opposed to lithostratigraphical mapping, discussion of the theories on the origin of granites and the sometimes overweening influence of dominant schools of thought.

Chapter 6 describes the work of the researchers who operated in the first half of

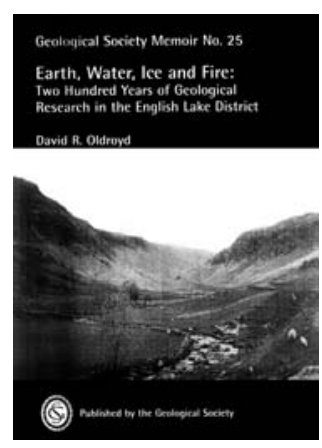

the twentieth century, when a concerted effort was made to map the Borrowdale Volcanic Group. However, there is a clear continuity of research in this period with the preceding century. At the beginning of the twentieth century the structural relationships between the three main stratigraphical units were still unclear and problems of rock identification in the volcanic succession that had emerged in the 1870 s were to remain intractable until the middle of the twentieth century.

Up to this point the author has had to rely entirely on documentary sources for his information. From Chapter 7, which starts to deal with research carried out after the end of the Second World War, the style of the book changes, as he has been able to interview many of the geologists who worked there. There is a journalistic feel to it in parts. All aspects of Lake District geology were reappraised. He charts the contribution made by the many $\mathrm{PhD}$ students, who brought new approaches and techniques to the study of granites and volcanic rocks (Chapter $7 \& 12$ ) and the stratigraphy and polyphase deformation of the Skiddaw Group (Chapters 8, 9 \& 12). Plate tectonics is introduced (Chapter 10) and the input of geophysics (Chapter 11) to reach understanding on the deep subsurface is described. Chapter 13 revisits the stratigraphical problems of the Windermere Supergroup. These chapters are dense with information, analysis and argument and provide a sturdy platform for the chapters on the modern period.

Chapter 14, which is an introduction to the modern period, is the least successful in the book. After a time in which there was little interest in the Lake District among academics, the British Geological Survey decided to enter the area in 1981 for the first time since 1877 in a collaborative project with university researchers. For the next twenty years the BGS and academics worked side by side in the area. The author makes much of the conflicts that emerged between the two sectors, concluding that some of what happened was "a bit depressing and unseemly". It is right, in a book of this sort, that these should be brought out, but in my view (as I was involved throughout I have to declare an interest) the author deals with them rather superficially. He gives them too much emphasis and makes little allowance for the inevitability of the clashes of ego, ideas and personality that happen when a number of bright, intelligent and ambitious researchers are concentrated in one place. When he moves on to the detail of the research carried out in this period, in the next three chapters (Chapters 15-17), the book moves up a gear. The account is full of detail and argument; it has pace and interest and is a joy to read.

Chapter 18 considers the matter of whether the Lower Palaeozoic rocks of the Lake District were ever covered by Mesozoic sediments. After this (Chapter 19) is an account of the research on the Quaternary deposits. While the former chapter describes a problem tackled by the most modern of methods, the other is an interesting account of the development of thought on glaciations through the nineteenth century. The penultimate chapter (Chapter 20) is about the investigations carried out to find a suitable repository for the deep burial of radioactive waste in concealed Borrowdale volcanic rocks on the western margin of the Lake District, an issue that is as much political as geological.

In the final chapter the author draws conclusions from and expresses his opinions on the diverse topics that emerge in the narrative. He expresses surprise that despite two hundred years of effort many problems remain unsolved and nothing truly novel has come out of the Lake District research. It is an odd conclusion to reach after having written what he did. The rocks of the Skiddaw Group are as complex and difficult to map as any in the world. The Borrowdales presents the level of detail of the anatomy of a volcano only available in ancient, upturned rocks and will never be easy to interpret. $\mathrm{He}$ clearly recognises this, but his stress on the negative in parts of the account of the modern period rather overshadows the wisdom of his final sentence: "Infinite complexity can never be described."

There are important lessons to be had from this book. It shows how the temporal, historical or even political context, the fashions and fads of the time, personal and scientific conflicts, the power of dominant personalities and even the health of an individual can have a bearing on how research is carried out and written up. It serves as a case history on the way long-term, geological research is conducted in a messy world where people have weaknesses, prejudices and egos. For this reason alone students should read it, but it is also an essential reference for anyone seeking detailed information specifically about what has been done in the Lake District.

\section{Peter Allen}

107 Grantham Rd

Bingham

Nottingham NG13 8DF

$U K$ 